\title{
A CROSS-SECTIONAL STUDY OF INTEGRATED CHILD DEVELOPMENT SERVICE SCHEME IN RAJASTHAN, HEALTH PROMOTIONAL- ISSUES AND CHALLENGES
}

\author{
Shiv Lal Bhardwaj1, Om Parkash Sharma²
}

1Professor, Department of Community Medicine, Jaipur National University of Institute for Medical Sciences and Research Centre, Jaipur, Rajasthan.

${ }^{2}$ Associate Professor, Department of Community Medicine, Jaipur National University of Institute for Medical Sciences and Research Centre, Jaipur, Rajasthan.

\begin{tabular}{l}
\hline ABSTRACT \\
BACKGROUND \\
Integrated Child Development Services (ICDS) scheme is a specific nutritional intervention launched since 1978 to combat \\
malnutrition through life cycle approach in children. The scheme is in operation in state for the past forty-five years. This study is a \\
scheme analysis designed to find the impact on its objectives.
\end{tabular}

\section{MATERIALS AND METHODS}

Study Design- A cross-sectional study. Study Units- Child Development Projects (CDPO) and Anganwadi Centres (AWC). Since the study duration was three years, the total sample size was 36 CDPO and 180 AWC, but we decided to study 39 CDPO and 442 AWC. Sample size was taken conveniently. Sampling- Simple random sampling was done.

Study Objectives- Evaluate the ICDS scheme in Rajasthan- its present status in Rajasthan.

Setting- Department of Community Medicine, JNU Medical College and Hospital, Jaipur-302017.

\section{RESULTS}

$64 \%$ of the beneficiaries were registered, $24 \%$ of them only availing supplementary nutrition. Hot supplementary food was cooked and served in all the AWC. The menu in all was found to be hot and sweet khichdi. The mean attendance of children was 5 only. $78 \%$ of the take-home food was not taken by beneficiaries, as it was stated to be stale and unfit for consumption. Vit A and IFA was given to all entitled. Deworming was done in all children. In 100\% of AWC Antenatal and Postnatal Clinics, immunisation were not undertaken by the Auxiliary Midwife as the facilities for their conduct were not available. $98 \%$ of the AWC were operating in a single room accommodation, of which $17 \%$ were not electrified. Moderate malnutrition prevalence in 0 - 3 years was $42 \%$, while in 3 - 6 it was overall $31.5 \%$ and $0.2 \%$ severe malnutrition overall. There has been significant reduction in severe malnutrition cases for the past 6 years $(\mathrm{p}<0.005)$.

\section{CONCLUSION}

The ICDS scheme has been in operation over more than 45 years in the state. It has succeeded in arresting increase in moderate malnutrition which is stagnant at $42 \%$ in 0 - 3 years of age, but has significantly reduced prevalence of severe malnutrition to $0.2 \%$ only ( $\mathrm{p}<005)$, while health aspect has shown marginal increase especially in immunisation increased to $88 \%$, but $72 \%$ of them were irregularly immunised giving partial immune status. The scheme is underutilised due to departmental inertia. ICDS has so far succeeded in reducing severe malnutrition. Other key indicators continue to be low. It raises doubts that should we continue with it? Can we really afford to continue feeding for long time to combat malnutrition or some other approach is required?

\section{KEYWORDS}

Anganwadi, AWW, AWC Child Development Projects, Malnutrition, ANM.

HOW TO CITE THIS ARTICLE: Bhardwaj SL, Sharma OP. A cross-sectional study of integrated child development service scheme in Rajasthan, health promotional- issues and challenges. J. Evolution Med. Dent. Sci. 2018;7(11):1413-1417, DOI: $10.14260 /$ jemds/2018/321

\section{BACKGROUND}

Malnutrition is often a manmade disease, which starts in the womb and ends in tomb. Government of India through its Department of Women and Child Development (DCWD) within the Ministry of Human Resource Development (MoHRD) is implementing a very specific intervention to break the vicious cycle of intergenerational malnutrition through Integrated Child Development Services (ICDS) scheme. ${ }^{1}$

'Financial or Other Competing Interest': None.

Submission 01-02-2018, Peer Review 24-02-2018,

Acceptance 02-03-2018, Published 12-03-2018.

Corresponding Author:

Dr. Shiv Lal Bhardwaj,

Professor, Department of Community Medicine,

Near New RTO Office,

Jaipur-302017, Rajasthan.

E-mail: birdy.shiv@gmail.com

DOI: $10.14260 /$ jemds $/ 2018 / 321$

The hypothesis is that under normal circumstances, the health of a mother largely determines the health of her child in the first 1000 days after birth. Care of mother during pregnancy and lactation will therefore yield rich dividend in terms of child health. Accordingly, the services in the scheme are supplementary nutrition including micronutrient to pregnant and lactating mothers, children up to age six years, immunisation, health check-up, preschool education, health, nutritional awareness and referral services. ${ }^{2}$ The vision of the scheme is holistic, physical, psychosocial, cognitive and emotional development of children by nurturing them in a protective, child-friendly environment. ${ }^{3}$

The scheme was launched on 02 Oct 75, initially in 34 projects in four states namely Rajasthan, MP, Bihar and UP. The first such project in Rajasthan was in Garhi (Banswara). ${ }^{4}$ Encouraged by its good results, the scheme was expanded in the entire country since 1978. Rajasthan now has 304 Child Development Projects (CDPO) and 54915 Anganwadi Centre 
(AWC) and 6908 mini Anganwadi for urban slums and Tribal hamlets (till 2016). ${ }^{4}$ The scheme is financed by Government of India and World Bank National Institute of Public Cooperation and Child Development (NIPCCD), New Delhi, gives training, monitors and evaluates the scheme in all the states. Towards this, the NIPCCD constitutes a central Monitoring unit (CMU) at each state headquarters, which apprise the institute of functioning status in the state. This study was undertaken to find if the ICDS scheme has really made any dent on the life cycle associated malnutrition after 45 years of its operation in the state, if not what could be the reasons and issues.

\section{MATERIALS AND METHODS}

\section{Study Design}

A cross-sectional study of ICDS scheme was undertaken.

\section{The Study Units}

Child Development Projects (CDPO) and Anganwadi Centres (AWC).

\section{Sampling}

The study units were selected by simple random sampling at two levels. Since the study duration was three years the total sample size was 36 CDPO and 180 AWC, but we decided to study 39 CDPO and 442 AWC. Sample size was taken conveniently.

\section{Instrument}

The data were collected by interview technique on a predesigned pretested format, which included actual check of records and stocks. The data were analysed and the statistical analysis was done.

\section{RESULTS}

The child development project located at Block level are the middle level working unit for support to field staff, supplies and monitor Anganwadi Centres (AWC) at village. The CDPO is also responsible to coordinate with link departments like health and education which become crucial at AWC level. Any insufficiency on his part will adversely affect the functioning of AWC. There are about 100 - 150 AWC in one project. The important observations on CDPOs are that-

a. $56 \%$ of the CDPO were part-time care taker, holding charge of multiple departments. Their involvement with project activities was least significant.

b. $\quad 48 \%$ of them were trained in any course in the scheme; untrained CDPO generally were under confident and could be poor leaders.

c. CDPO have financial power to procure stocks, supplies and pay for miscellaneous work in the field like organising camps. This is the weakest area of scheme where no accountability is fixed for CDPO in terms of expenditure and outcome. By the time irregularity is detected everything is settled. Neither auditors nor the higher-up are bothered. We strongly feel that here we need to put people who have proven record of honesty and integrity. Just to support our argument we give example of CDPO Jaisalmer and Pokhran who were making payments to Self Help Group (SHG). We tried to find the reason. The CDPO commented it is none of your concern. We raised the level and the answer was standard reply that we will look into the matter. d. $8 \%$ vacancies of the supervisor and $21 \%$ of the ACPDO are vacant. AWC are poorly supervised.

e. $100 \%$ of the supervisors are females and each has to supervise 20-30 AWC per month, meaning thereby that at least one AWC has to be visited every day. The facilities for movement are left to themselves to organise.

f. There is no system of recording attendance, most CDPO come to office only in the afternoon, they take break at their own will and do not come to office for days together. The only staff available at office is a clerk and computer operator. It appeared to us that scheme is running on auto mode, there seem to be nobody to take care at CDPO level. The project level efficiency largely depends upon officer in charge, his concern, his initiative, his discipline and above all dedication to work largely and a little support he gets from higher-ups including RDD and Director. For the extent of concern, it is noteworthy to quote an example of that Director of Scheme in State (Dr. S. Sharma, IAS) himself came to street level for underutilisation, he went house to house to plead that the community should use AWC, it is for their good that we have opened. Now this is the type of leadership expected at all level, but unfortunately the same is missing at CDPO level. The CDPO take pride in coming late and sitting for few hours that too once in a while probably just to mark their attendance. Their attendance recording system is also faulty or has been made so. This includes Supervisors also, where they are nobody knows. This casual attitude to the job is the area of concern that should be immediately addressed, discipline has to be enforced, attendance should be biometric and accountability for the work should be fixed for CDPO and his staff. This also reflect lax attitude of RDD.

The services to beneficiaries are delivered by coordinated effort of AWW and Auxiliary Nurse Midwife (ANM) working at sub-centre and village nominated Sahayogni. This trio at village level forms the nucleus, which ultimately makes it a success of the scheme. Their work includes visiting ten houses daily in addition to work at AWC. The location of the AWC is either in school or close to it, so the facilities could be shared. The activities are conducted from this place for three to four hours depending upon weather conditions. The timely supplies and stocking is the job of CDPO. The package services to be provided are same as mentioned earlier, but the utilisation by community participation depends on quality of rapport or the confidence the trio of AWW, ANM and Sahayogni enjoys. The AWC is the hub centre of all the activities of the scheme, supplementary feedings to the beneficiaries, preschool activities, growth check-ups and care of mothers and adolescent girls was sub-optimal in most of the AWC. The meals are supposed to be cooked at AWC and given hot to beneficiaries. While in case of pregnant and lactating women, take-home ready-to-eat food of soya-cereal mix, Rajasthan special is also given, but not consumed. ANM conducts Antenatal and Postnatal clinics, (ANC and PNC) and immunisations not at $\mathrm{AWC}$ but at sub-centres. She is supposed to give priority for referred cases to $\mathrm{PHC}$ or $\mathrm{CHC}$ or $24 \mathrm{x} 7 \mathrm{PHC}$, FRU. The main observations affecting operations at this level were-

a) $28 \%$ of the AWW are graduates and above, and among these $50 \%$ are postgraduates, overqualified workers are unsuitable as AWW as they are poorly motivated, belonging mostly to upper casts and have rich background, having good political connections, barring few none of them come to AWC. 
b) $40 \%$ was the level of registration of beneficiaries and among those registered very few of them come to AWC. It was found that only $24 \%$ use the services of supplementary nutrition, mean attendance was found to be 5 children per day on visit day, while the registered beneficiaries were far more than attendance on the day of visit.

c) Near $100 \%$ of the AWC centres are located in one room, where all the activities of AWC are undertaken including stores, cooking, feeding etc., which is inadequate and crowded if full strength of beneficiaries are present. $23 \%$ had no toilet facilities at all.

d) $78 \%$ of the AWC are not equipped well to undertake the task as per the charter of duty equipment like Infantometer, stadiometer, weighing, Salter or electronic machine were not available or were in unusable state.

e) $17 \%$ of the AWC are not electrified and there is lack of comforts like air cooling.

f) $2 \%$ of AWC are located in mixed kutcha dwelling very close to sewage ponds where mosquitoes were in abundance, had no drinking water, no electricity.

g) The items issued to AWC like Durry and Utensils were taken away by Gram Panchayat and not returned. (The statement could not be verified since no village head could be contacted).

h) AWW are most often asked to do work not related to ICDS like conducting surveys of below poverty line, Aadhar scheme and other miscellaneous works which consume their time for at the cost of scheme.

i) AWC have no facilities for the conduct of ANC, PNC, Health check-ups and immunisation by ANM. These activities are done at sub-centre level, so the record of these is duplicated and inflated data are created.

j) One ANM has 4 - 5 AWC under her area. She is often not able to attend all the AWC during the month, as she is busy with many activities at sub-centre.

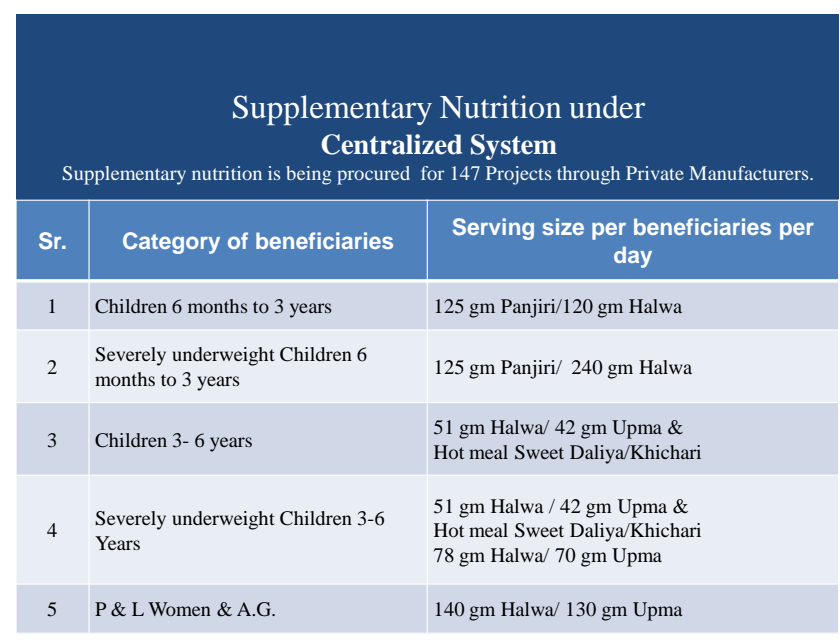

\begin{tabular}{|c|c|c|c|c|}
\hline $\begin{array}{c}\text { Age } \\
\text { Group }\end{array}$ & $\begin{array}{c}\text { Total } \\
\text { Registered/ } \\
\text { Weighted }\end{array}$ & Normal & $\begin{array}{c}\text { Grade } \\
\text { I and II }\end{array}$ & $\begin{array}{c}\text { Grade } \\
\text { III and IV }\end{array}$ \\
\hline 0-3 years & $30100 / 25121$ & 18970 & 5523 & 636 \\
\hline 3-6 years & $16830 / 14220$ & 11014 & 3015 & 191 \\
\hline \multicolumn{4}{|c|}{ Nutritional Status of the Children } \\
\hline
\end{tabular}
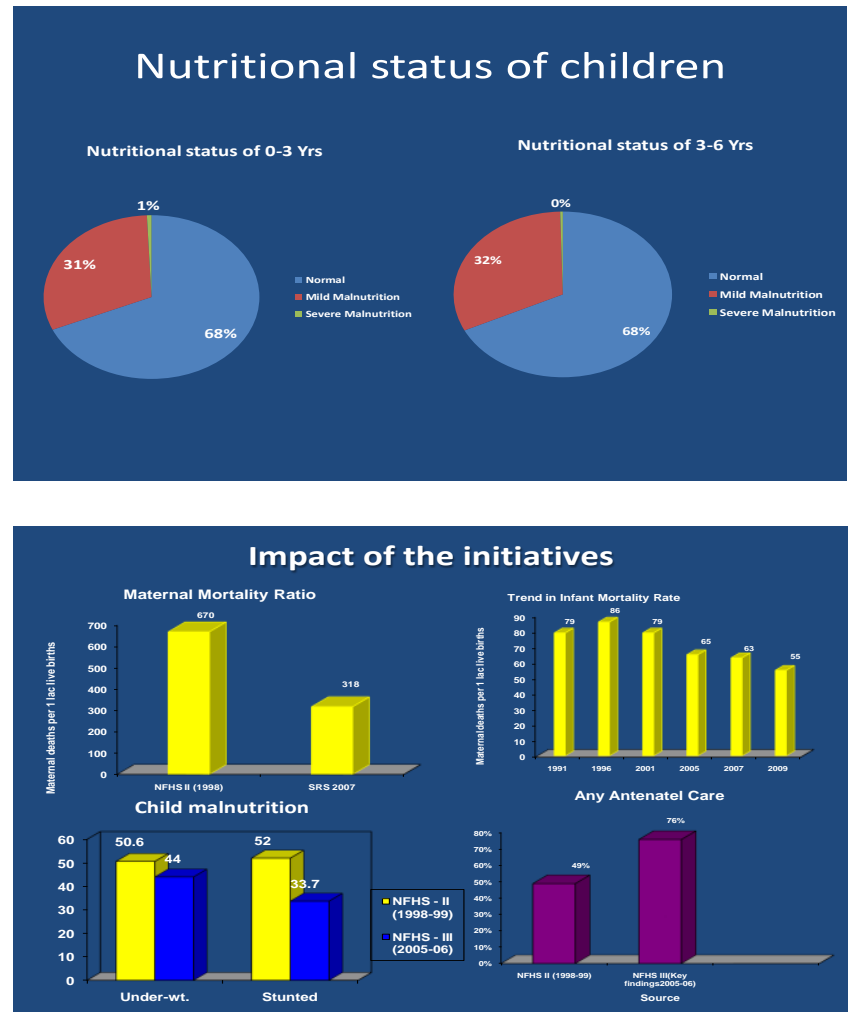

Tables- A cross-sectional study of ICDS in Rajasthan Health Promotion- Issues and Challenges.

\begin{tabular}{|c|c|c|c|c|}
\hline $\begin{array}{c}\text { Age } \\
\text { Group } \\
\text { of Children }\end{array}$ & $\begin{array}{c}\text { Total } \\
\text { Registered }\end{array}$ & Normal & $\begin{array}{c}\text { Moderately } \\
\text { Under } \\
\text { Weight } \\
\end{array}$ & $\begin{array}{c}\text { Severely } \\
\text { Under } \\
\text { Weight }\end{array}$ \\
\hline $\begin{array}{c}\text { 0-3 years } \\
\text { Girls } \\
\text { Boys }\end{array}$ & $\begin{array}{l}21967 \\
30195\end{array}$ & $\begin{array}{c}19175 \\
(87.29 \%) \\
24196 \\
(80.1) \\
\end{array}$ & $\begin{array}{c}2768 \\
(12.60 \%) \\
3711 \\
(12.29 \%) \\
\end{array}$ & $\begin{array}{l}24(0.01 \%) \\
25(0.08 \%)\end{array}$ \\
\hline $\begin{array}{c}\text { 3-6 years } \\
\text { Girls } \\
\text { Boys }\end{array}$ & $\begin{array}{l}19338 \\
19440\end{array}$ & $\begin{array}{c}17063 \\
(88.23 \%) \\
17174 \\
(88.34 \%) \\
\end{array}$ & $\begin{array}{c}1601 \\
(8.27 \%) \\
1859 \\
(9.56 \%) \\
\end{array}$ & $\begin{array}{l}19(0.09 \%) \\
19(0.09 \%)\end{array}$ \\
\hline Total & 98336 & $\begin{array}{c}77608 \\
(78.92 \%)\end{array}$ & $\begin{array}{c}9939 \\
(10.10 \%)\end{array}$ & $\begin{array}{c}87 \\
(0.08)\end{array}$ \\
\hline
\end{tabular}

\begin{tabular}{|c|c|c|}
\hline & Qty. Held & Qty. Serviceable \\
\hline PSE Kit & 492 & 492 \\
\hline Weight Machine & 326 & 326 \\
\hline Growth Chart & 326 & 326 \\
\hline Registers & 326 & 326 \\
\hline Referral Slips & 242 & 242 \\
\hline MPR Forms & 335 & 335 \\
\hline Medicine Kit & 492 & 492 \\
\hline NHED Kit & 85 & 85 \\
\hline Referral Slips & 242 & 242 \\
\hline MPR Forms & 335 & 335 \\
\hline Medicine Kit & 492 & 492 \\
\hline NHED Kit & 85 & 85 \\
\hline
\end{tabular}

\begin{tabular}{|c|c|c|c|c|}
\hline Sl. No. & $\begin{array}{c}\text { Project } \\
\text { Type }\end{array}$ & $\begin{array}{c}\text { No. of } \\
\text { Projects }\end{array}$ & AWC & $\begin{array}{l}\text { Mini } \\
\text { AWC }\end{array}$ \\
\hline 1 & Rural & 228 & 42345 & 4913 \\
\hline 2 & Urban & 40 & 5287 & 1573 \\
\hline 3 & Tribal & 36 & 7283 & 1178 \\
\hline Total & & 304 & 54915 & 6248 \\
\hline
\end{tabular}




\begin{tabular}{|c|c|c|c|}
\hline Post & $\begin{array}{c}\text { Number } \\
\text { Authorized }\end{array}$ & $\begin{array}{c}\text { Number } \\
\text { Posted }\end{array}$ & $\begin{array}{c}\text { Training } \\
\text { Status Any } \\
\text { Course }\end{array}$ \\
\hline CDPO & 304 & $289(95.06 \%)$ & $48 \%$ \\
\hline ACDPO & 304 & $267(87.82 \%$ & $39 \%$ \\
\hline Supervisors & 864 & $860(99.53 \%)$ & $100 \%$ \\
\hline AWW & 61823 & $61823(100 \%)$ & $100 \%$ \\
\hline Helper & 61823 & $\begin{array}{c}61808 \\
(99.97 \%)\end{array}$ & $99.80 \%$ \\
\hline \multicolumn{4}{|c|}{ Table 2. Manning and Training State } \\
\hline
\end{tabular}

\begin{tabular}{|c|c|c|}
\hline Sl. No. & Service & Beneficiaries \\
\hline 1 & $\begin{array}{c}\text { Supplementary } \\
\text { Nutrition }\end{array}$ & 6 months - 6 years \\
\hline 2 & Preschool Education & 3 - 6 years \\
\hline 3 & $\begin{array}{c}\text { Nutritional and Health } \\
\text { Education }\end{array}$ & $\begin{array}{c}15-45 \text { yrs. Women and } \\
\text { Adolescent Girls }\end{array}$ \\
\hline 4 & Immunisation & $\begin{array}{c}0-6 \text { yrs. Children and } \\
\text { Pregnant Women }\end{array}$ \\
\hline 5 & Health Check-Ups & $\begin{array}{c}\text { Pregnant, Lactating, } \\
\text { Adolescent Girls and 0 - 6 } \\
\text { years Children }\end{array}$ \\
\hline 6 & Referral & $\begin{array}{c}\text { 0 - 6 years, Adolescent, PW } \\
\text { and LW }\end{array}$ \\
\hline \multicolumn{2}{|c|}{ Table 3. Services and Beneficiaries } \\
\hline
\end{tabular}

\begin{tabular}{|c|c|}
\hline Item & Qty. Held \\
\hline PSE Kit & $75.69 \%$ \\
\hline Weight Machine & $93.65 \%$ \\
\hline Growth Chart & $93.06 \%$ \\
\hline SNP (Utensil) & $95.05 \%$ \\
\hline Registers & $95.04 \%$ \\
\hline Referral Slips & $11.06 \%$ \\
\hline MPR Forms & $99.90 \%$ \\
\hline Medicine Kit & $76.38 \%$ \\
\hline NHED Kit & $89.04 \%$ \\
\hline \multicolumn{2}{|c|}{ Table 4. Equipment and Other Items at $\boldsymbol{A W C}$} \\
\hline
\end{tabular}

\begin{tabular}{|c|c|c|c|}
\hline Year & $\begin{array}{c}\text { Normal } \\
\mathbf{0 - 3} 3-6\end{array}$ & $\begin{array}{c}\text { Moderate } \\
\mathbf{0 - 3} 3-6\end{array}$ & $\begin{array}{c}\text { Severe } \\
\mathbf{0 3} 3-6\end{array}$ \\
\hline $\begin{array}{c}\text { 2013-14 } \\
\text { Male }\end{array}$ & 56.0275 .51 & 43.4521 .98 & 0.530 .026 \\
Female & 52.1959 .85 & 47.4239 .89 & 0.390 .0 .002 \\
\hline $\begin{array}{c}2014-15 \\
\text { Male }\end{array}$ & 59.8852 .91 & 39.8039 .80 & 0.330 .33 \\
Female & 84.4949 .32 & 42.2938 .70 & 0.30 .13 \\
\hline $\begin{array}{c}2015-16 \\
\text { Male }\end{array}$ & 80.1088 .23 & 12.2912 .60 & 0.080 .08 \\
Female & 87.2978 .92 & 8.279 .56 & 0.090 .08 \\
\hline \multicolumn{4}{|c|}{ Table 5. Nutritional Status Impact of the Scheme } \\
\hline
\end{tabular}

\section{DISCUSSION}

The nutritional status of the beneficiaries 0-3 years of age continue to be stagnant between $40 \%-45 \%$ and for $3-6$ of age it is $43.5 \%$ for rural and $30.1 \%$ for urban children and in overall $31.5 \%$ moderate and $0.2 \%$ severely nourished were the findings during study. If the data are compared to year 2011, where the percentage of children $0-6$ years who were moderately malnourished was $45.54 \%$ of which $17.3 \%$ were severely stunted and $2.9 \%$ were severely wasted, which has come down to $0.31 \%$ level in 6 years. This include both sexes, $(\mathrm{p}<0.005)$ is a remarkable achievement. 5 Why this is not seen in moderate malnutrition is a question to be answered. Many studies have revealed that moderate malnutrition is often resilient to respond, as feeding 3 - 6 years of age become often difficult. ${ }^{6}$ In addition if only $24 \%$ of the beneficiaries consume supplementary nutrition and rest not, may contribute to persisting moderate malnutrition, but reasons for low registration should be investigated. In our study, we found $100 \%$ of the pregnant and lactating women were given four or more ANC and IFA tablets for hundred days. But NFHS IV reports much lower figures, only $25 \%$ in urban and $14.8 \%$ in rural areas for hundred days. This much difference in figures can only be explained of cooked up figures in ICDS scheme, since we relied on recorded documents at AWC. The numbers of institutional deliveries have certainly increased to near $90.3 \%$ and same has been reported by other studies, particularly in urban slums, but change perhaps due to financial reward under Janani Suraksha Yojna (JSY), both for mother and Accredited Social Health Activist.7.5,6 This increase in institutional deliveries has reduced neonatal mortality and given impetus to promotion of breast feeding. 8 If the mothers had gone full ANC as in ICDS data, then why LBW at 28\%. The data of full ANC are of any indication the ANC Rajasthan rural areas continue to be low at $7.4 \%$, then again there is element of doubt in ICDS functioning. Immunisation, Infant Mortality and Maternal Mortality Rate, Under Five Mortality and Unmet Mortality Rate stands respectively at IMR at 31 in urban and 44 in rural area, 48 per thousand live births, immunisation continues to remain at $89 \%$ for TT, $83 \%$, DPT $79.2 \%$, Measles and BCG 84\%, OPV 83\% and MMR 244/1000 not a very acceptable state, but needs further push on real ground. ${ }^{9,8}$ The immunisation in about $72 \%$ of cases is irregular and not as per the schedule. This raises false sense of protection since protective seroconversion is not achieved. ${ }^{10}$ Lastly, a debate on supplementary feeding, several eminent experts in nutrition says that a nation cannot afford to keep on feeding its population to combat malnutrition, for gains other related factors often rooted in social factors have also to be dealt with. ${ }^{11,12,13}$

\section{CONCLUSION}

The study has shown that there has been significant decrease in severe malnutrition prevalence $(p<0.005)$, while moderate malnutrition continue to be high but showing trend decreases. Now it is a question if this decrease is causally attributed to ICDS scheme or it is a spontaneous occurrence out of decrease in poverty and increased food production. If the other indicators like immunisation, meeting unmet family planning needs, care of mother and child during pregnancy and lactation which have pathetic figures of performance, do we need ICDS any more, a costly venture to continue? Can ICDS claim a success in these areas? No. We need to have total overhaul of the scheme, people unmotivated and are of doubtful integrity need to be weeded out immediately. We need to focus more on the scheme and look at it as service to humanity and not a welfare organisation highly politicised. It is low output scheme in Rajasthan and should ideally be done away, but need to be given chance once for some time more, so better to continue with hope that ICDS will yield better results in future.

\section{ACKNOWLEDGEMENTS}

We are thankful to the Director, ICDS Mahila and Balvikas Mantralaya, Govt. of Rajasthan for permitting us to conduct the study in the state. We are also thankful to Director NIPCCD, New Delhi for technical guidelines and making us evaluators on their behalf. 


\section{REFERENCES}

[1] Park KE. Social welfare programme. Integrated child development services. In: Park 'text book of preventive and social medicine. 23rd edn. m/s Jabalpur India. Banarsidas Bhanot, 2015:590-4.

[2] Kishor J. National Program of India. Integrated child development services (ICDS) scheme. In: National Health Programs of India. $12^{\text {th }}$ edn. New Delhi. Century Publication, 2017:495-502.

[3] Gupta RP. Health care reforms in India: making up for the lost decades. ICDS scheme. In: Health care Reforms in India. $1^{\text {st }}$ edn. Manesar Delhi. Elsevier, 2016;3:141.

[4] Elizabeth KE. Tripple burden of malnutrition. In: nutrition \& child development. $5^{\text {th }}$ edn. Hyderababd, New Delhi. Paras publication, 2015:pp 241.

[5] Singh R, Shaikh S, Hassan MA, et al. Effect of ensured ante-natal care on birth outcome: a community-based interventional study. Health and Population 2014;37(3 \& 4):88-97.

[6] Bhardwaj SL, Rathore MS, Archana P. Infant feeding practices and early neonatal care amongst ethical tribe of Rajasthan. The Anthropologist 2012;14(5):459-65.

[7] Dey S, Raheem E, Sarkar P. Identifying the factors influencing institutional and non institutional delivery practices in slums of Shillong city. Health \& Population Prospective \& Issues 2014;37(3-4):76-87.
[8] Key Indicators of Rajasthan. National Family Health Survey 4. National Institute of Population Studies. Mumbai, Statistics on Rajasthan. 2016;2-4.

[9] National Institute of Public Cooperation and Child Development. Statistics on Children in India. Hand book. 2014:207-13.

[10] The Times of India. National family health survey 4 . $72 \%$ of children not getting definated on time survey. 2018;2(6.3).

[11] Park KE. Child health problems. Malnutrition In Park Text Book of Preventive and Social Medicine. 23 ${ }^{\text {rd }}$ edn. Jabalpur, m/s Banarsidas Bhanot, 2015:549-50.

[12] World Health Organization. World Health Statistics. Monitoring of Health for the sustainable Development Goals. Gnenva, 2017.

[13] Alkema L, Chou D, Hogan D, et al. Global and regional nutritional levels and trends in maternal mortality between 1990 and 2015, with scenario based projection to 2030: a systemic analysis by the UN maternal mortality estimation inter agency group. Lancet 2016;387(10017):462-74. 